\title{
Cost of Producing Processed Oranges in Southwest Florida in 2017/18
}

\author{
Ariel Singerman ${ }^{2}$
}

In this article I present estimates for the cost of production per acre for processed oranges grown in southwest Florida in $2017 / 18$. Typical users of these estimates include growers and consultants, who use them as a benchmark; property appraisers, who use them to compute the taxes for property owners; and researchers, who use the estimates to evaluate the economic feasibility of potential new technologies.

A total of ten growers participated in the cost of production data collection process by attending a meeting that took place at the UF/IFAS Extension office in LaBelle in May 2018. As done in previous years, the day of the meeting growers brought a completed survey form that had been distributed to them beforehand. The questionnaire asked growers to provide annual, per-acre costs by program for a "typical" irrigated, mature grove (10+ years old), including costs related to their tree replacement program.

During the meeting, each grower used a "clicker" or remote device to enter the costs for each caretaking program. Using clickers to collect the data ensured that the process was anonymous and confidential. Surveying a panel of growers to obtain the costs of their production programs allows us to report estimates that closely reflect growers' cost. This is particularly important because, since the outbreak of HLB, growers have been modifying their practices from year to year in an attempt to cope with the disease. However, the cost estimates below do not represent any individual operation. Instead, their purpose is to serve as a benchmark for the Florida citrus industry.
The figures below were obtained by computing the weighted average of the responses by the acreage of each of the participating growers. The number of acres managed by their combined operations accounts for approximately 57,000 acres. The latest acreage for oranges in southwest Florida was estimated at 260,214 (USDA-NASS 2018). Thus, the sample of growers represented $22 \%$ of the acreage devoted to oranges in that region.

Table 1 shows the cultural costs of production by program. The estimates include both the costs of materials and the costs associated with their application. The total cost for weed management, which includes chemical and mechanical mowing as well as herbicides, was $\$ 194.67$ per acre. At $\$ 640.11$ per acre, foliar sprays represented the largest production cost. Fertilizer was the second largest expense at $\$ 496.43$ per acre. Citrus Health Management Areas (CHMA) sprays accounted for $\$ 44.48$ per acre. The expense for pruning was $\$ 30.42$ per acre, while that for irrigation was $\$ 214.32$ per acre. Adding all the costs listed above, the cultural cost of growing oranges for processing during 2016/17 without tree replacement was $\$ 1,620.41$ per acre.

Growers were also asked to provide details regarding their reset practices, including the number of trees replaced in their groves. On average, growers replaced seven trees per acre during 2017/18. The total cost of tree replacement, including tree removal, site preparation, and supplemental care of those seven young trees, was estimated at $\$ 254.38$ per acre. Adding this figure to the total cost above yields a

1. This document is FE1056, one of a series of the Food and Resource Economics Department, UF/IFAS Extension. Original publication date April 2019. Visit the EDIS website at https://edis.ifas.ufl.edu for the currently supported version of this publication. 
total production cost with tree replacement of $\$ 1,874.79$ per acre.

Figure 1 depicts a double pie chart. The larger pie shows the cost of each program as well as the percentage relative to the total cultural production costs with tree replacement. The smaller pie in Figure 1 provides greater detail regarding the individual components included in the foliar sprays. Insecticides accounted for $\$ 192.58$ per acre, representing $10 \%$ of the cultural cost of production; fungicides accounted for $\$ 70.26$ per acre (4\%); foliar nutritionals for $\$ 132.91$ per acre (7\%); aerial application totaled $\$ 20.77$ per acre (1\%), and ground application of materials was $\$ 172.86$ per acre $(9 \%)$.

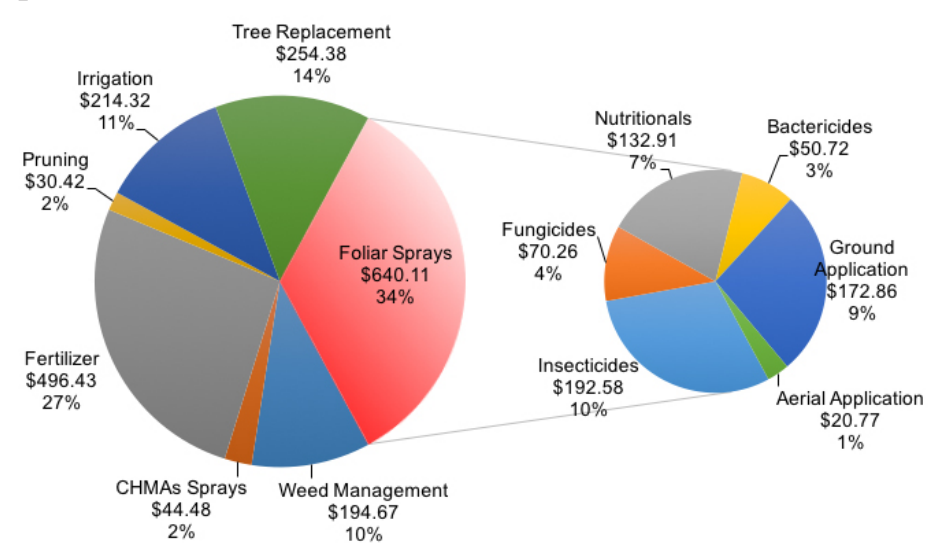

Figure 1. Cultural costs of production (in dollars per acre) for processed oranges grown in southwest Florida, 2017/18.

Figure 2 shows a comparison of the cost of the main production programs in $2017 / 18$ relative to $2016 / 17$. The main changes in cultural practices in 2017/18 compared to the previous season are as follows. First, there was an increase of $\$ 84$ per acre in fertilizer spending. This was due to a switch from dry to liquid fertilizer. The rationale for this change is based on the successful experience of some growers in "spoon-feeding" trees to increase yield. The second-largest change was a reduction in tree replacement; growers are spending approximately $\$ 10$ per tree less on young tree care during the trees' first three years. The third-largest change was a reduction in streptomycin and oxytetracycline spending; growers reported spending, on average, \$51 per acre, down from \$94 last season.

In addition to cultural costs, growers typically have to incur in other costs when managing their groves; these other costs include management, regulatory, and opportunity costs. Table 2 shows the total cost of production for processed oranges grown in southwest Florida during 2017/18 was $\$ 2,334.72$ per acre. Based on this estimate, the breakeven prices per box and per pound solids for different levels of yield are presented in Table 3. Break-even prices were calculated on an on-tree and delivered-in basis. The latter assumes harvesting costs per box were $\$ 3.09$, which is based on the results of Singerman and Burani-Arouca (2018). The calculations in Table 3 also include the Florida Department of Citrus (FDOC) assessment of $\$ 0.07$ per box for the 2017/18 season. Thus, for example, the on-tree and delivered-in break-even prices for covering the total costs of production with yield at 150 boxes per acre were $\$ 2.75$ and $\$ 3.31$ per pound solids, respectively.

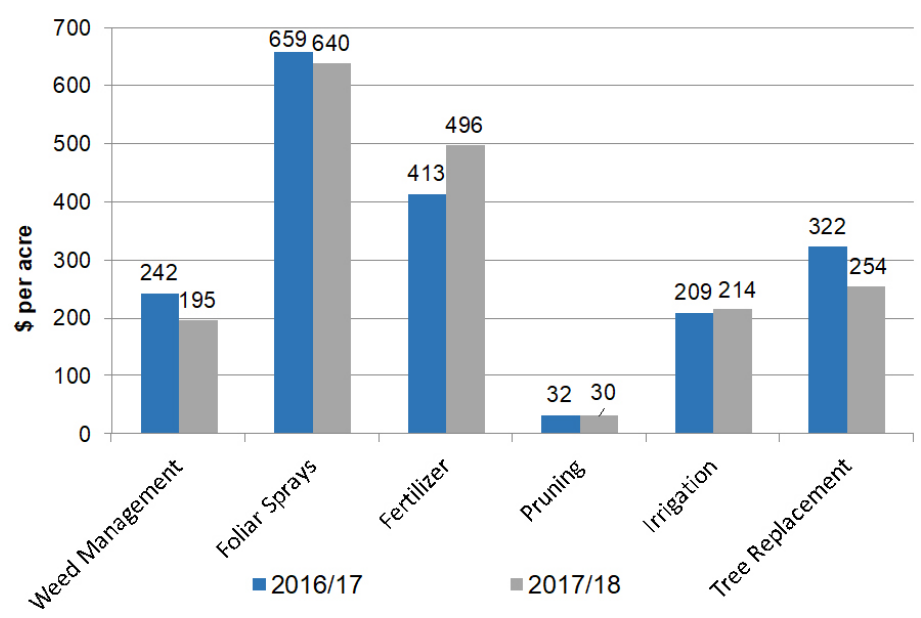

Figure 2. Cost of production by program for processed oranges grown in southwest Florida, 2016/17 vs. 2017/18.

\section{Summary}

This article presents a summary of the 2017/18 costs of production for processed oranges grown in southwest Florida. The methodology chosen to collect the data consisted of surveying growers directly to closely reflect growers' costs in the era of HLB. The main change this season was the increase in fertilizer spending as growers attempt to "spoon-feed" HLB-affected trees to increase yield. The total cost of production for Processed Oranges in 2016/17 was $\$ 2,334.72$ per acre.

\section{References}

Singerman, A. and M. Burani-Arouca. 2018. Harvesting Charges for Florida Citrus, 2017/18. Available at: http:// www.crec.ifas.ufl.edu/extension/economics/harvesting_charges.shtml

USDA-NASS. 2018. Florida Citrus Statistics 2016/17. Available online at: https://www.nass.usda.gov/Statistics_by_State/Florida/Publications/Citrus/Citrus_Statistics/2016-17/fcs1617.pdf 
Table 1. Cultural Costs of Production per Acre for Processed Oranges Grown in Southwest Florida, 2017/18.

\begin{tabular}{|c|c|c|c|c|}
\hline $\begin{array}{l}\text { Costs represent a mature grove (10+ } \\
\text { years old) including resets }\end{array}$ & $\begin{array}{l}\text { Number of } \\
\text { Applications }\end{array}$ & $\begin{array}{l}\text { Materials Cost per } \\
\text { acre (\$) }\end{array}$ & $\begin{array}{l}\text { Application Cost per } \\
\text { acre (\$) }\end{array}$ & Total Cost per acre (\$) \\
\hline \multicolumn{5}{|l|}{ Cultural Costs } \\
\hline \multicolumn{5}{|l|}{ Weed Management } \\
\hline Mowing (Chemical \& mechanical) & 5 & 3 & 52.94 & 55.94 \\
\hline Herbicides & 4 & 88.18 & 50.55 & 138.73 \\
\hline \multicolumn{4}{|l|}{ Total Weed Management Costs } & 194.67 \\
\hline \multicolumn{5}{|l|}{ Foliar Sprays } \\
\hline Insecticides & & 192.58 & & \\
\hline Fungicides & & 70.26 & & 446.48 \\
\hline Nutritionals & & 132.91 & & \\
\hline Bactericides & & 50.72 & & \\
\hline \multicolumn{5}{|l|}{ Application: } \\
\hline Ground & 8 & & 172.86 & 172.86 \\
\hline Aerial & 3 & & 20.77 & 20.77 \\
\hline \multicolumn{4}{|l|}{ Total Foliar Sprays Costs } & 640.11 \\
\hline CHMAs Sprays & 7 & & 44.48 & 44.48 \\
\hline \multicolumn{4}{|l|}{ Total CHMAs Sprays Costs } & 44.48 \\
\hline \multicolumn{5}{|l|}{ Fertilizer } \\
\hline Ground/Dry Fertilizer & 3 & 253.88 & 24.08 & 277.97 \\
\hline Fertigation/Liquid Fertilizer & 16 & 157.91 & 60.55 & 218.46 \\
\hline \multicolumn{4}{|l|}{ Total Fertilizer Costs } & 496.43 \\
\hline \multicolumn{5}{|l|}{ Pruning } \\
\hline Topping \& Hedging & 1 & & 25.92 & 25.92 \\
\hline Chop/Mow Brush & 1 & & 4.50 & 4.50 \\
\hline \multicolumn{4}{|l|}{ Total Pruning Costs } & 30.42 \\
\hline \multicolumn{5}{|l|}{ Irrigation } \\
\hline Irrigation System ${ }^{1}$ & & & & 157.26 \\
\hline Fuel for pump & & & & 57.06 \\
\hline \multicolumn{4}{|l|}{ Total Irrigation Costs } & 214.32 \\
\hline \multicolumn{4}{|c|}{ Total Cultural Production Costs without Tree Replacement } & $1,620.41$ \\
\hline \multicolumn{5}{|l|}{ Tree Replacement (7 trees) } \\
\hline \multicolumn{4}{|c|}{ Tree Removal (Clip-shear; use front-end loader) } & 47.10 \\
\hline \multicolumn{4}{|c|}{ Site Preparation and Plant Tree (Includes reset trees) } & 80.11 \\
\hline \multicolumn{4}{|c|}{ Supplemental Fertilizer, Sprays, Sprout, etc. (Trees 1-3 years old) } & 127.17 \\
\hline \multicolumn{4}{|l|}{ Total Tree Replacement Costs } & 254.38 \\
\hline \multicolumn{4}{|c|}{ Total Cultural Costs with Tree Replacement } & $1,874.79$ \\
\hline
\end{tabular}


Table 2. Total Costs of Production per Acre for Processed Oranges Grown in Southwest Florida, 2017/18.

\begin{tabular}{|c|c|c|}
\hline & & Total Cost per acre (\$) \\
\hline \multicolumn{2}{|c|}{ Total Cultural Costs } & $1,874.79$ \\
\hline \multirow[t]{4}{*}{ Other Costs } & Interest on Operating (Cultural) Costs & 93.74 \\
\hline & Management Cost & 141.12 \\
\hline & Property Tax/Water Management Assessment & 28.73 \\
\hline & Interest on Average Capital Investment & 196.35 \\
\hline \multicolumn{2}{|c|}{ Total Other Cost } & 459.93 \\
\hline \multicolumn{2}{|l|}{ Total Costs } & 2334.72 \\
\hline
\end{tabular}

Table 3. Break-Even Price per Box and per Pound Solids for Processed Oranges Grown in Southwest Florida, 2017/18.

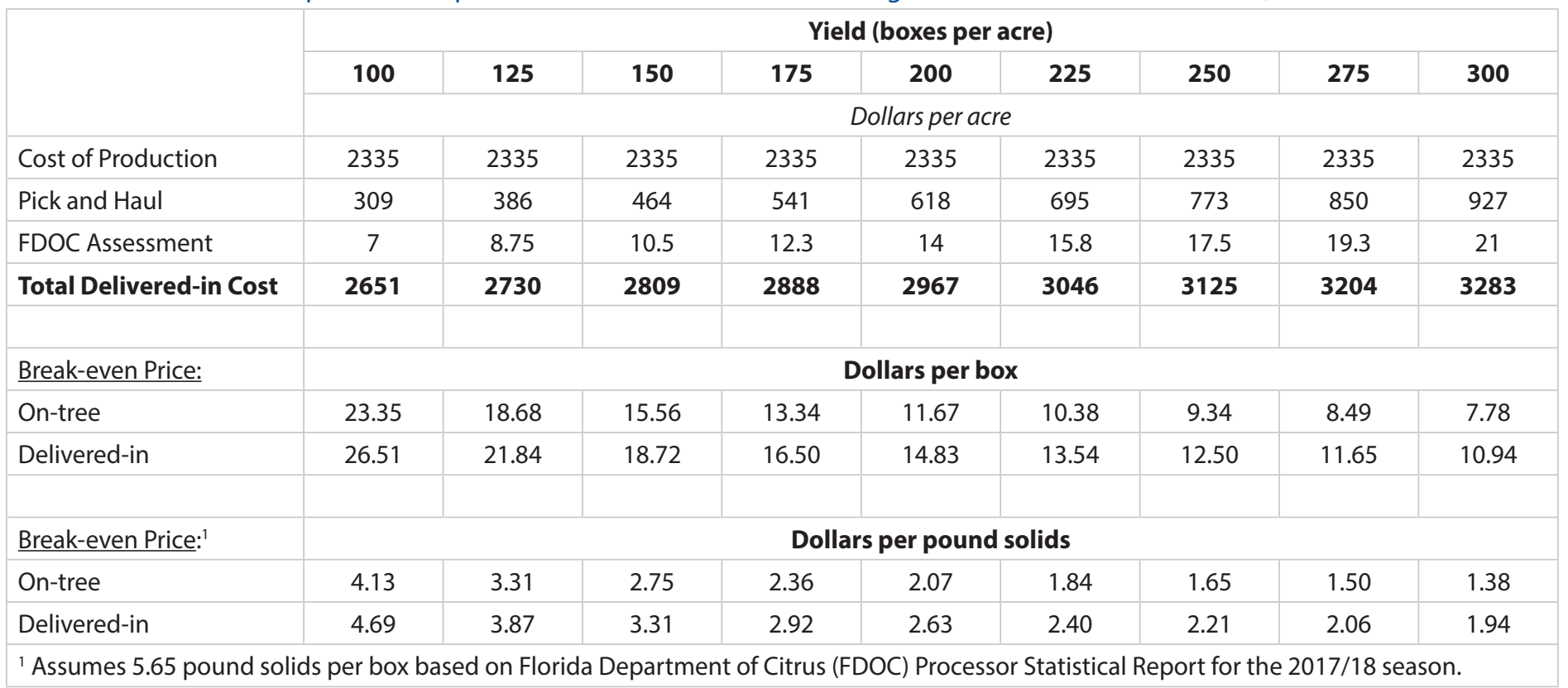

